Nevşehir Bilim ve Teknoloji Dergisi TARGíD Özel Sayı 385-394 2016

DOI: 10.17100/nevbiltek.211026

URL: http://dx.doi.org/10.17100/nevbiltek.211026

\title{
Zaman Serileri Yöntemiyle Orta Anadolu Bölgesinin (TR-7) 2023 Yılı Traktör Varlığı ve Güç Büyüklüğü Tahmini
}

\author{
M. Zahid Malasl1 ${ }^{1 *}$, Talha Bekir Özmen², Ahmet Çelik² \\ ${ }^{1}$ Bingöl Üniversitesi, Ziraat Fakültesi, Biyosistem Mühendisliği Bölümü, Bingöl \\ ${ }^{2}$ Atatürk Üniversitesi, Ziraat Fakültesi, Tarım Makinalarl ve Teknolojileri Mühendisliği Bölümü,
} Erzurum

Öz

Tarımsal üretimde temel güç kaynağı olan traktör, aynı zamanda ülkelerin tarımsal mekanizasyon göstergelerinin belirlenmesinde dikkate alınan önemli parametrelerin başında yer almaktadır. Türkiye'de tarımsal üretimdeki artışa paralel olarak traktör imalatı ve satışı da giderek artmaktadır. Bitki deseninin çeşitlenmesiyle birlikte, üreticilerin farklı tarım alet ve makinalarına ihtiyacı artmakta ve buna bağlı olarak daha büyük güce sahip traktörler tercih edilmektedir. Bu durum hem traktör sayısında, hem de ortalama güç büyüklügünde artışa yol açmaktadır.

Bu çalışmada, Türkiye İstatistik Kurumu (TÜIK) tarafından oluşturulan istatistiki bölge birimleri sınıflandırmasına göre; Aksaray, Kayseri, Kırıkkale, Kırşehir, Nevşehir, Niğde, Sivas ve Yozgat illerini kapsayan Orta Anadolu Bölgesi’nin (TR-7) 1991-2014 yılları arasındaki traktör varlığı ve güç büyüklüğ̈ dağılımı incelenerek, 2023 yılı için bu dağılımın izleyeceği seyrin belirlenmesi amaçlanmıştır. Bu amaçla, TÜiK verileri kullanılarak, zaman serileri yöntemi ile tüm güç sınıfları için modeller oluşturulmuş ve bu modellerden gelecek senaryoları hazırlanmıştır.

Elde edilen sonuçlara göre, son 24 yılda Türkiye genelinde traktör sayısı \% 76,5 oranında artarken, Orta Anadolu Bölgesinde \% 60,4 oranında artış ile traktör sayısı 78620'den 126128 'e çıkmıştır. Ayrıca, Türkiye'nin ortalama traktör gücü büyüklüğü \% 7,7 artışla 36,28 kW'tan 39,09 kW'a çıkarken, Orta Anadolu Bölgesinde \% 7,6 artış ile ortalama güç 38,90 kW’tan 41,85 kW’a çıkmışıtır.

Anahtar Kelimeler: Orta Anadolu Bölgesi, ortalama traktör gücü, traktör varlığı, zaman serileri

\section{Estimation of Number of Tractors and Force Size for the Region Central Anatolia (TR -7) with Time Serious Method by the Year 2023}

\begin{abstract}
Tractor, which is basic power supply in agricultural production, is also among the most important parameters that taken into account in determining the agricultural mechanization indicator of the countries. Manufacturing and sales of tractors in Turkey increase in parallel with the increase in agricultural production. With the diversification of cropping pattern, for manufacturers the need for different agricultural machinery increases and accordingly tractors with greater force are preferred. This case leads to an increase in both the size of the average power and the number of tractors. By analyzing the tractor existence and power size distribution between 1991 and 2014 of the provinces of Central Anatolia (TR-7) covering; Aksaray, Kayseri, Kırıkkale, Kırşehir, Nevsehir, Nigde, Sivas and Yozgat according to the statistical classification of units created by Turkey Statistical Institute (TSI), this study aims to determine the course to be followed by the distribution for the year 2023. For this purpose, by using the TSI data, models for all power classes are formed with time series management and future scenarios of these models were prepared.

According to the obtained results, in the last 24 years, the number of tractors across Turkey increased by 76,5 \%, and with an increase of 60,4 \% in the Central Anatolia region the total number of tractors in Turkey has increased from 78620 to 126128.

In addition, while the average size of tractor power in Turkey increased from 36,28 $\mathrm{kW}$ to 39,09 with an increase by 7,7 \%, the aerage power in the Central Anatolia region increased from 38,90 kW to 41,85 kW with an increase by 7,6 \%.
\end{abstract}

Keywords: Central Anatolian Region, average tractor power, number of tractors, time series

"e-mail: mzmalasli@bingol.edu.tr 
1. Giriş

Dünya genelinde nüfus artı̧̧ına paralel olarak gıda ihtiyacı giderek artmaktadır. Bu bağlamda tarımsal üretimde artan talebi karşılayabilmek amacıyla birim alandan daha yüksek verim elde etmek gerekmektedir. Bu amaçla, sürekli gelişime açık olan; sulama, gübreleme, ilaçlama, kaliteli tohumluk ve tarımsal mekanizasyon gibi temel tarım teknolojilerinden yararlanılmaktadır. Tarımsal mekanizasyon, diğer tarım teknolojilerinin uygulanması ve etkinliklerinin arttırılması yönünden de oldukça büyük bir öneme sahiptir [1].

Tarımda mekanizasyon işlemleri, çok büyük oranda traktörle çalıştırılan iş makineleri ile gerçekleştirilmektedir [2]. Traktör, aynı zamanda mekanizasyon yatırımlarının en önemli bölümünü oluşturmaktadır. Ülkelerin tarımsal mekanizasyon düzeylerinin belirlenmesinde dikkate alınan göstergelerin başında traktör parkının nitelik ve nicelik yönündeki durumu, yıllara göre değişimi ile işlenen birim alandaki yoğunluğu gibi veriler gelmektedir. Bu göstergeler çeşitli yörelerin iklim, toprak özellikleri ve tarımsal yapısındaki farklılıklara bağlı olarak değişiklik göstermektedir [3].

Orta Anadolu Bölgesi, Kayseri, Yozgat, Sivas, Kırşehir, Nevşehir, Kırıkkale, Aksaray ve Niğde illerini kapsamaktadır. Bölgenin yüzölçümü 91539 km² olup, Türkiye yüzölçümünün \% 11,23’ünü teşkil etmektedir [4].

Tarım makinaları alanında çeşitli amaçlar doğrultusunda regresyon analizi ile yapılmış bazı çalışmalar mevcuttur. Yapılan bir araştırmada; pülverizatörde, çalışma basıncı ve meme delik çapının damla büyüklüğü üzerindeki etkisi doğrusal regresyon modelle ifade edilmiştir [5]. Diğer bir çalışmada ise, çiftçilerin traktör satın alma gücünü açıklayan lojistik regresyon modeli oluşturulmuştur [6].

Bu çalışmada, Orta Anadolu Bölgesine ait 1991-2014 yılları arasındaki traktör sayısı ve ortalama traktör gücü verilerine göre, tarımda ve teknolojide meydana gelen gelişmeler doğrultusunda Orta Anadolu Bölgesi illerinin, Bölge ortalamasının ve Türkiye genelinin traktör sayısının ve ortalama traktör gücünün nasıl bir seyir izleyeceği araştırılmıştır.

\section{Materyal ve Metot}

Çalışmanın materyalini Türkiye İstatistik Kurumu (TÜIK) tarafından oluşturulan istatistiki bölge birimleri sınıflandırmasına göre; Aksaray, Kayseri, Kırıkkale, Kırşehir, Nevşehir, Niğde, Sivas ve Yozgat illerini kapsayan Orta Anadolu Bölgesi’nin (TR-7) 1991-2014 yıllarına ait Türkiye İstatistik Kurumu'ndan (TÜIK) alınan traktör verileri oluşturmuştur. Bu amaçla, Orta Anadolu Bölgesindeki iller, Orta Anadolu Bölge ortalaması ve Türkiye’ye ait traktör verileri kullanılarak, traktör güç sınıflarına göre toplam güç büyüklüğü ve ortalama traktör gücü tespit edilmiştir. Bu veriler kullanılarak, traktör parkı ve ortalama traktör gücü ile ilgili 2023 yılı tahmini yapmak için zaman serisi yönteminden yararlanılmıştır.

Zaman serisi verileri, bir dönemden diğerine, değişkenlerin ardışık olarak gözlendiği sayısal değerlerdir. Belirli bir süre içerisinde elde edilen, ardışık dönemlerdeki mevcut verileri kullanarak olayın yapısının analiz edilmesi ve geleceğine ilişkin tahminlerin yapılabilmesinin en uygun ve kolay yolu zaman serisi analizidir [7]. Zaman serilerinde regresyon analizi ile çeşitli modellemeler yapılabilir. Bu modellerin bazıları; $Y=\beta_{0}+\beta_{1} X+\varepsilon$ şeklinde doğrusal regresyon modeli [8], $Y=\beta_{0}+\beta_{1} X+\beta_{2} X^{2}+$ $\varepsilon$ şeklinde karesel regresyon modeli [9], $Y=\beta_{0}+\beta_{1} X+\beta_{2} X^{2}+\beta_{3} X^{3}+\varepsilon$ şeklinde kübik regresyon modeli [10], $Y=e^{\beta_{0}+\beta_{1} X} \varepsilon$ şeklinde üstel regresyon modeli [11] ve $Y=\beta_{0} X^{\beta_{1}}$ şeklinde güç regresyon 
modelidir [9]. Burada; $Y$ : bağımlı değişken, $X, X^{2}$ ve $X^{3}$ ise ilgili modele ait bağımsız değişkenlerdir. $\beta_{0}$ sabit değer olup, $\beta_{1}, \beta_{2}$ ve $\beta_{3}$ ilgili modele ait parametrelerin katsayılarıdır.

Regresyon modelleri uygulanırken verilerin normal dağılıma uygunluğu, hata terimlerinin sabit varyanslı olması, hata terimleri arasında otokorelasyon (ardışık bağımlılık) sorununun olmaması [12] gibi gerekli varsayımların sağlanması gerekir. Uygulanan zaman serisi yönteminde, Orta Anadolu Bölgesinde yer alan iller, bölge ortalaması ve Türkiye geneli için en uygun regresyon modeli belirlenmiştir. Uygun regresyon modelini belirlemede, denenen farklı modeller içerisinde belirleme katsayısı $\left(R^{2}\right)$ en yüksek olan [13] ve standart hatası en küçük olan model tercih edilmiş̧ir.

Uygun olmayan regresyon yöntemlerinin kullanılması hatalı ve yanıltıcı sonuçların elde edilmesine neden olmaktadır. Regresyon analizinde incelenen değişkenler sürekli ya da kesikli yapıda olabilmektedir ve bu veri yapısına bağlı olarak farklı regresyon modelleri kullanılabilmektedir [14].

\section{Bulgular}

Orta Anadolu Bölgesi’ndeki iller, Orta Anadolu Bölgesi ve Türkiye için ileriye yönelik traktör park1 ile ilgili tahmin yapabilmek amacıyla; parametre tahminleri anlamlı bulunan uygun regresyon modelleri, belirleme katsayısı, standart hata ve F testi sonuçları Tablo 1'de verilmiştir.

Buna göre, Kurşehir $\mathrm{Y}=5174,826+94,324 \mathrm{X}$ ve Orta Anadolu Bölgesi için Y=79985,960+2111,577X şeklinde doğrusal regresyon modeli elde edilmiştir. Bağımsız değişkenin bağımlı değişkeni açıklama oranları sırasıyla $\mathrm{R}^{2}=0,858$ (\% 85,8) ve $\mathrm{R}^{2}=0,937$ (\% 93,7)'dir. Kayseri $\mathrm{Y}=8697,912+191,735 \mathrm{X}+9,844 \mathrm{X}^{2}$, ve Niğde $\mathrm{Y}=4947,525+1082,781 \mathrm{X}+-24,416 \mathrm{X}^{2}$ şeklinde karesel regresyon modeli olarak ifade edilmiştir. Belirtme katsayıları $\left(R^{2}\right)$ sırasıla 0,969 ve 0,913 olarak hesaplanmıştır. Aksaray; $Y=7939,509+1136,655 X-72,439 X^{2}+1,617 X^{3}$, Sivas $Y=11151,961+816,699 X-$ $36,795 X^{2}+0,733 X^{3}$ ve Türkiye geneli için $Y=635734,555+43940,393 X-1958,915 X^{2}+48,479 X^{3}$ şeklinde kübik regresyon modeli olarak bulunmuştur.

Aksaray ve Sivas illeri ile Türkiye genelinin belirtme katsayıları sırasıyla 0,914, 0,967 ve 0,988 olarak bulunmuştur. Kırıkkale'nin 2023 yılı traktör parkı tahmininde $\mathrm{Y}=\mathrm{e}^{5986,047+0,010 \mathrm{X}}$ şeklinde üstel regresyon modeli olarak belirlenmiş ve belirtme katsayısı 0,688 olarak elde edilmiştir. Nevşehir $\mathrm{Y}=9725,848 \mathrm{X}^{0,171}$ ve Yozgat illeri için ise $\mathrm{Y}=17308,807 \mathrm{X}^{0,111}$ şeklinde güç regresyon modeli uygun bulunmuştur. Bu iller için belirtme katsayıları sırasıyla 0,891 ve 0,791 olarak elde edilmiştir.

Orta Anadolu Bölgesi’ndeki illerin traktör parkının 1991-2014 yılları arasındaki değişimi Şekil 1'de verilmiştir. Buna göre, yıllar içerisinde dalgalanmalar olsa bile tüm illerin traktör sayısında önemli artı̧̧lar meydana gelmiştir. Bu durum, bölge çiftçisinin 24 yıllık dönemde alım gücünün arttığı, üretimini yaptıkları bitki çeşidindeki artış ile birlikte kullandıkları alet ve ekipman sayısı ve çeşidindeki değişimin traktör parkına da olumlu şekilde yansıdığı şeklinde açıklanabilir.

Bölgede, traktör sayısının en fazla arttı̆g il \% 112,22'lik artışla Kayseri olmuştur. Kayseri’yi, \% 94,24 ile Niğde, \% 66,05 ile Aksaray ve \% 65,66’lık artışla Sivas illeri izlemiştir. Traktör sayısının en az arttığ 1 iller sırasıyla \% 33,13 ile Yozgat, \% 36,59 ile Kırıkkale ve \% 39,43'lük artışla Kırşehir illeri olmuştur. Buna göre, Yozgat'ta traktör sayısı 17996'dan 23944'e, Kırıkkale'de 5464'den 7463'e ve Kırşehir'de 5427'den 7567'ye yükselmiştir. 
Malaslı MZ., Özmen TB., Çelik A.

Tablo 1. Traktör parkı için regresyon analizi sonuçları

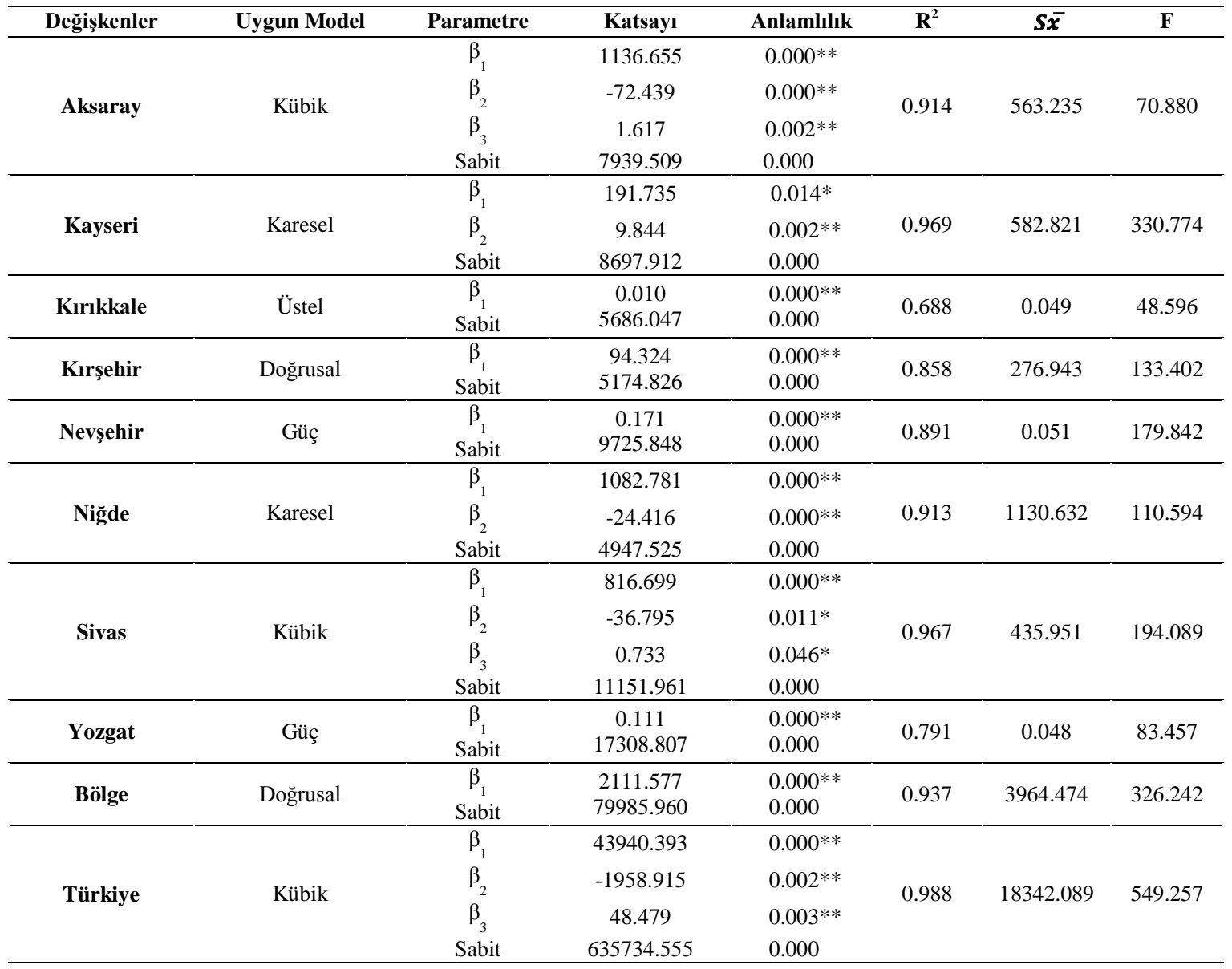

$*(\mathrm{P}>0.05), * *(\mathrm{P}<0.01)$

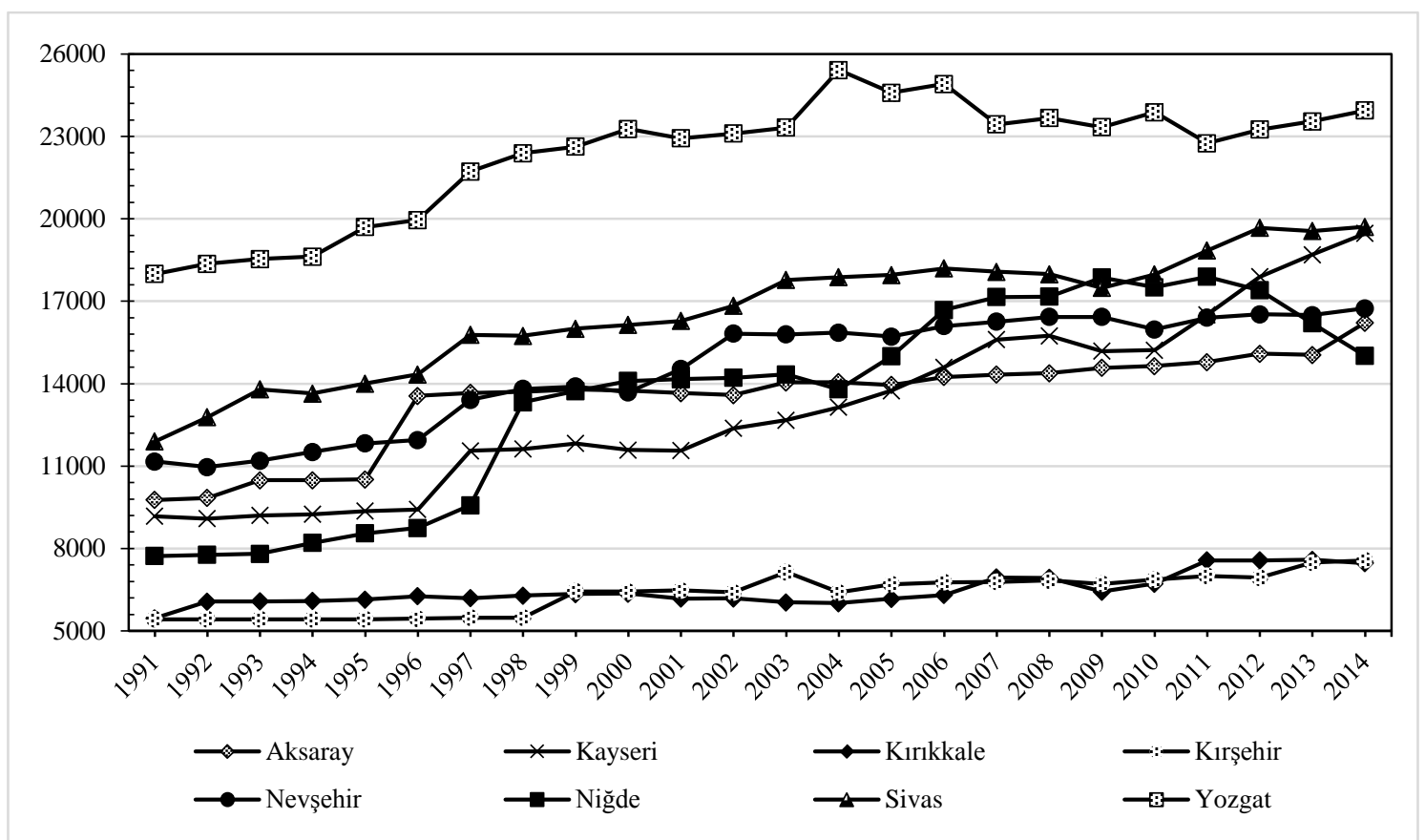

Şekil 1. Orta Anadolu Bölgesi'ndeki illerin 1991-2014 yılları arasındaki traktör parkı değişimi [15] 
Orta Anadolu Bölgesi’nin 1991-2014 yıllarına ait traktör parkındaki değişim Şekil 2'de verilmiştir. Bölgedeki illerde meydana gelen artışa paralel olarak Orta Anadolu Bölgesi’nin traktör sayısı \% 60,44'lük artış ile 78620'den 126128'e yükselmiştir. Türkiye'nin 1991-2014 yılları arasındaki traktör parkı grafiği Şekil 3’te verilmiştir. Bu süre içerisinde ülkemizin traktör sayısı \% 76,51 artarak 704373'den 1243300'e çıkmıştır.

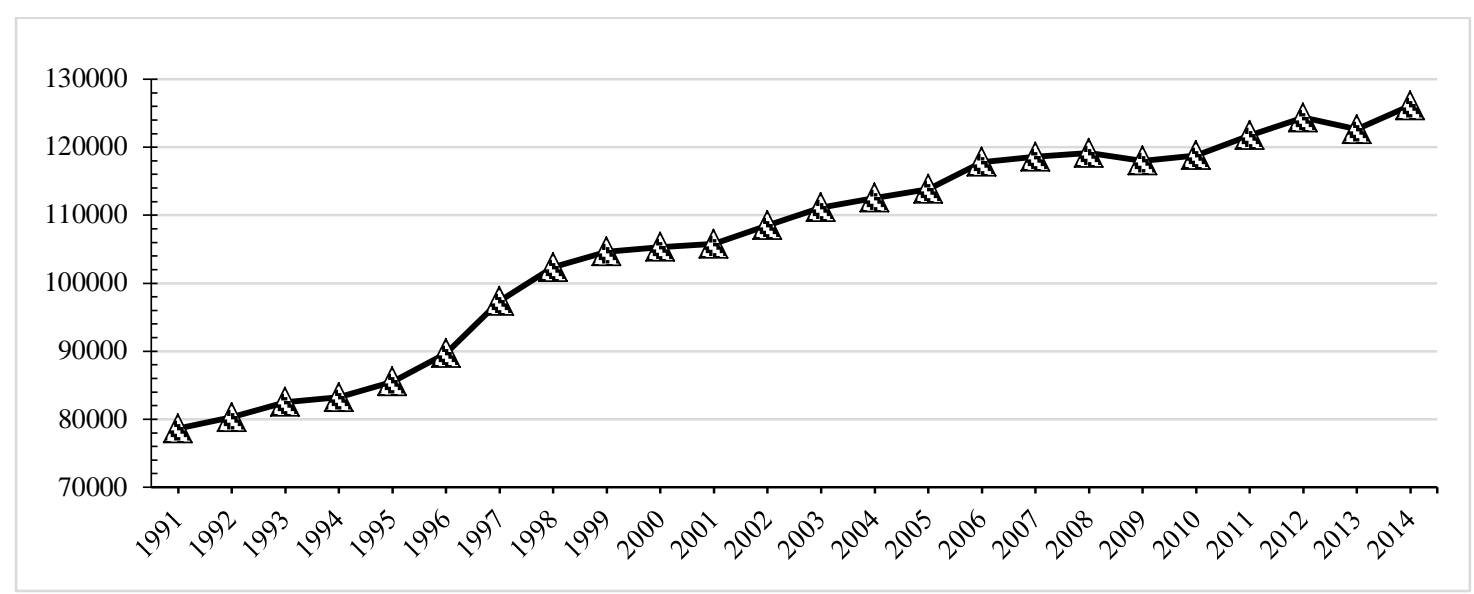

Şekil 2. Orta Anadolu Bölgesi'nin 1991-2014 yılları arasındaki traktör parkı değişimi [15]

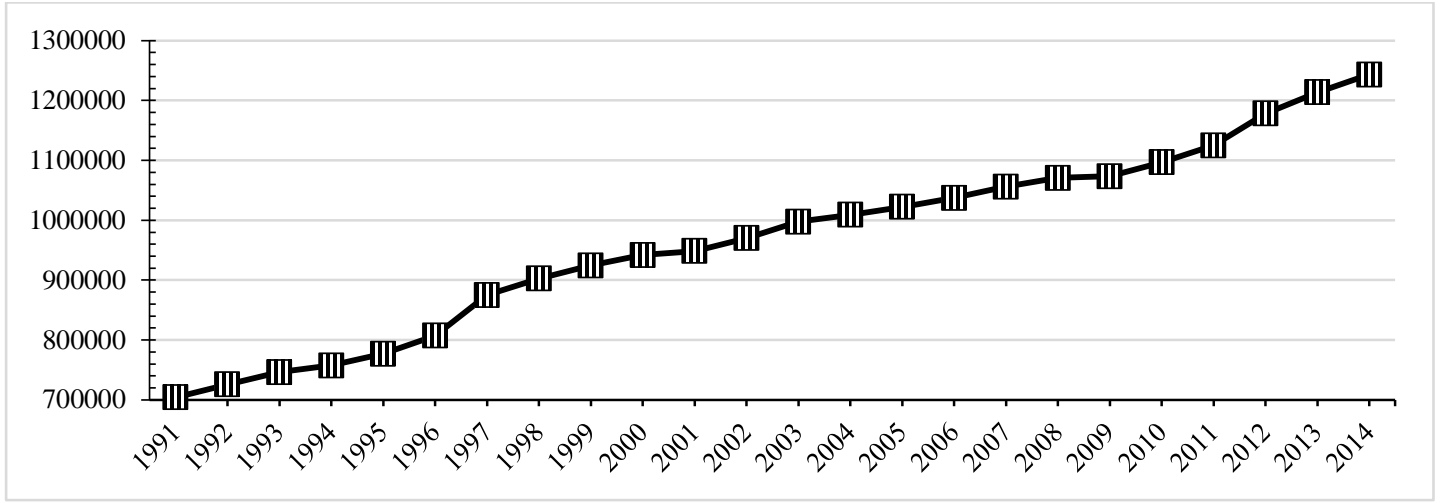

Şekil 3. Türkiye'nin 1991-2014 yılları arasındaki traktör parkı değişimi [15]

Orta Anadolu Bölgesi’ndeki iller, Orta Anadolu Bölgesi ve Türkiye için ileriye yönelik ortalama traktör gücü ile ilgili tahmin yapabilmek amacıyla; parametre tahminleri anlamlı bulunan uygun regresyon modelleri, belirleme katsayısı, standart hata ve F testi sonuçları Tablo 2'de verilmiştir.

Buna göre, Aksaray için ileriye dönük güç tahmininde $Y=44,085+-0,666 X+0,020 X^{2}$ ve Nevşehir için $\mathrm{Y}=43,199+-0,657 \mathrm{X}+0,025 \mathrm{X}^{2}$ şeklinde karesel regresyon modeli uygun bulunmuştur. Bu iller için bağımsız değişkenin bağımlı değişkeni açıklama oranları sırasıyla $R^{2}=0,801\left(\%\right.$ 80,1) ve $R^{2}=0,584(\%$ 58,4)'dür. Kırıkkale ili için $\mathrm{Y}=38,303+1,401 \mathrm{X}-0,103 \mathrm{X}^{2}+0,002 \mathrm{X}^{3}$ şeklinde kübik regresyon modeli belirlenmiş ve belirleme katsayısı 0,769 olarak elde edilmiştir. Üstel regresyon modelinin uygun bulunduğu iller ve bu illere ait belirtme katsayıları; Kayseri $\mathrm{Y}=\mathrm{e}^{34,841+0,011 \mathrm{X}}\left(\mathrm{R}^{2}=0,830\right)$, Kırşehir $Y=e^{41,663+0,003 X}\left(R^{2}=0,794\right)$, Niğde $Y=e^{38,990+-0,004 X}\left(R^{2}=0,636\right)$, Sivas $Y=e^{33,545+0,011 X}\left(R^{2}=0,900\right)$ şeklinde olmuştur. Orta Anadolu Bölgesi ve Türkiye için de üstel regresyon modeli belirlenmiştir. Buna göre, Orta Anadolu Bölgesi için $\mathrm{Y}=\mathrm{e}^{38,886+0,002 X}$ ve Türkiye geneli için $\mathrm{Y}=\mathrm{e}^{36,193+0,003 \mathrm{X}}$ şeklinde belirlenmiş ve 
belirtme katsayıları sırasıyla 0,819 ve 0,966 olarak elde edilmiştir. Yozgat ili için ise $\mathrm{Y}=38,959 \mathrm{X}^{0,020}$ şeklinde güç regresyon modeli uygun bulunmuştur ve belirtme katsayısı 0,541 olarak elde edilmiştir.

Tablo 2. Ortalama traktör gücü için regresyon analizi sonuçları

\begin{tabular}{|c|c|c|c|c|c|c|c|}
\hline Değişkenler & Uygun Model & Parametre & Katsayı & Anlamlılık & $\mathbf{R}^{2}$ & $S \bar{x}$ & $\mathbf{F}$ \\
\hline \multirow{3}{*}{ Aksaray } & \multirow{3}{*}{ Karesel } & $\beta_{1}$ & -0.666 & $0.000 * *$ & \multirow{3}{*}{0.801} & \multirow{3}{*}{0.764} & \multirow{3}{*}{42.220} \\
\hline & & $\beta_{2}$ & 0.020 & $0.000^{* *}$ & & & \\
\hline & & Sabit & 44.085 & 0.000 & & & \\
\hline \multirow[b]{2}{*}{ Kayseri } & \multirow{2}{*}{ Üstel } & $\beta_{1}$ & 0.011 & $0.000 * *$ & \multirow[b]{2}{*}{0.830} & \multirow[b]{2}{*}{0.037} & \multirow{2}{*}{107.603} \\
\hline & & Sabit & 34.841 & 0.000 & & & \\
\hline \multirow{4}{*}{ Kırıkkale } & \multirow{4}{*}{ Kübik } & $\beta_{1}$ & 1.401 & $0.000 * *$ & \multirow{4}{*}{0.769} & \multirow{4}{*}{1.032} & \multirow{4}{*}{22.217} \\
\hline & & $\beta_{2}$ & -0.103 & $0.003^{* *}$ & & & \\
\hline & & $\beta_{3}$ & 0.002 & $0.032 *$ & & & \\
\hline & & Sabit & 38.303 & 0.000 & & & \\
\hline \multirow{2}{*}{ Kırşehir } & \multirow[b]{2}{*}{ Üstel } & $\beta_{1}$ & 0.003 & $0.000 * *$ & \multirow[b]{2}{*}{0.794} & \multirow[b]{2}{*}{0.012} & \multirow[b]{2}{*}{84.982} \\
\hline & & Sabit & 41.663 & 0.000 & & & \\
\hline \multirow{3}{*}{ Nevşehir } & \multirow{3}{*}{ Karesel } & $\beta_{1}$ & -0.657 & $0.000 * *$ & \multirow{3}{*}{0.584} & \multirow{3}{*}{0.988} & \multirow{3}{*}{14.764} \\
\hline & & $\beta_{2}$ & 0.025 & $0.000 * *$ & & & \\
\hline & & Sabit & 43.199 & 0.000 & & & \\
\hline \multirow{2}{*}{ Niğde } & \multirow{2}{*}{ Üstel } & $\beta_{1}$ & -0.004 & $0.000 * *$ & \multirow{2}{*}{0.636} & \multirow{2}{*}{0.021} & \multirow{2}{*}{38.373} \\
\hline & & Sabit & 38.990 & 0.000 & & & \\
\hline \multirow{2}{*}{ Sivas } & \multirow{2}{*}{ Kübik } & $\beta_{1}$ & 0.011 & $0.000 * *$ & \multirow{2}{*}{0.900} & & \\
\hline & & Sabit & 33.545 & 0.000 & & 0.026 & 198.880 \\
\hline Yozgat & Güc & $\beta_{1}$ & 0.020 & $0.000^{* *}$ & 0.541 & 0016 & 25954 \\
\hline Yozgat & जuç & Sabit & 38.959 & 0.000 & 0.341 & 0.010 & 25.954 \\
\hline & Üstel & $\beta_{1}$ & 0.002 & $0.000 * *$ & & & \\
\hline Bolge & Ustel & Sabit & 38.886 & 0.000 & 0.819 & 0.008 & 99.734 \\
\hline & Üstel & $\beta_{1}$ & 0.003 & $0.000^{* *}$ & & 0.004 & 616.637 \\
\hline Turkiye & Ustel & Sabit & 36.193 & 0.000 & 0.966 & 0.004 & $010.03 /$ \\
\hline
\end{tabular}

$*(\mathrm{P}>0.05),{ }^{* *}(\mathrm{P}<0.01)$.

Orta Anadolu Bölgesi’nde yer alan illerin 1991-2014 yılları arasındaki ortalama traktör gücü değişimi Şekil 4'te verilmiştir. Buna göre, Aksaray ve Niğde illerinin ortalama traktör gücünde sırasıyla \% 5,96 ve 4,76 şeklinde azalma olmuştur. Bu illerde, traktör sayısındaki artışa rağmen ortalama traktör gücünün azalması; bu illerdeki üreticilerin traktör satın alırken sahip oldukları arazi varlığı ve ihtiyaç duydukları alet ve makinaların kapasitelerine göre bilinçli tercih yaptıkları ve gereğinden fazla büyük güçte traktör almadıkları şeklinde açıklanabilir.

Ortalama traktör gücündeki en fazla artış Kayseri ve Sivas illerinde olmuştur. Kayseri'de ortalama traktör gücü 35,37 kW’tan 43,63 kW'a, Sivas’ta ise 35,68 kW’tan 43,08 kW'a çıkmıştır. 2014 yılı verilerine göre Orta Anadolu Bölgesi’ndeki iller içerisinde en düşük ortalama traktör gücüne sahip il $36,58 \mathrm{~kW}$ ile Niğde, en yüksek ortalama traktör gücüne sahip il ise 45,79 kW ile Kırşehir olmuştur.

Orta Anadolu Bölgesi ve Türkiye’nin 1991-2014 yılları arasındaki ortalama traktör gücüne ilişkin değişim Şekil 5’te görülmektedir. Burada, Türkiye’nin ortalama traktör gücü \% 7,75 artarak 36,28 kW’tan 39,09 kW'a çıkmıştır. Orta Anadolu Bölgesi'ne ait ortalama traktör gücü ortalaması ise \% 7,58 artarak 38,90 kW'tan 41,85 kW'a yükselmiştir. 


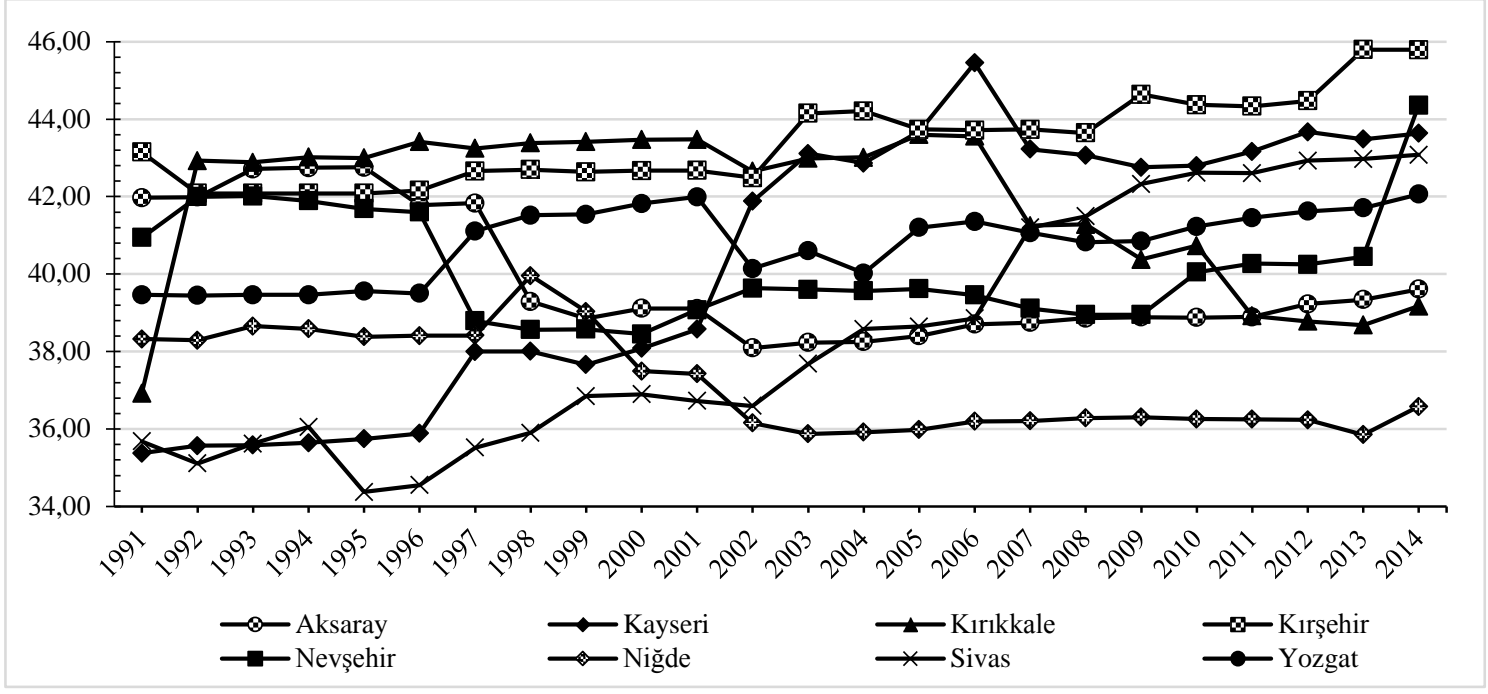

Şekil 4. Orta Anadolu Bölgesi'ndeki illerin 1991-2014 yılları arasındaki ortalama traktör gücü değişimi [15]

Elde edilen verilere göre, Bölge'nin ortalama traktör gücü ortalamasının Türkiye'nin ortalamasından yüksek olduğu görülmektedir. Ayrıca, son 24 yıllık dönemde hem Bölge hem de Türkiye ortalamasındaki bu artış; üreticilerin giderek daha büyük alet ve makina kullanımına yöneldiğini, üretimi yapılan bitki çeşidindeki artışın farklı birçok makina kullanmayı gerektirdiğini ve bunun içinde daha güçlü traktörlerin tercih edildiğini göstermektedir.

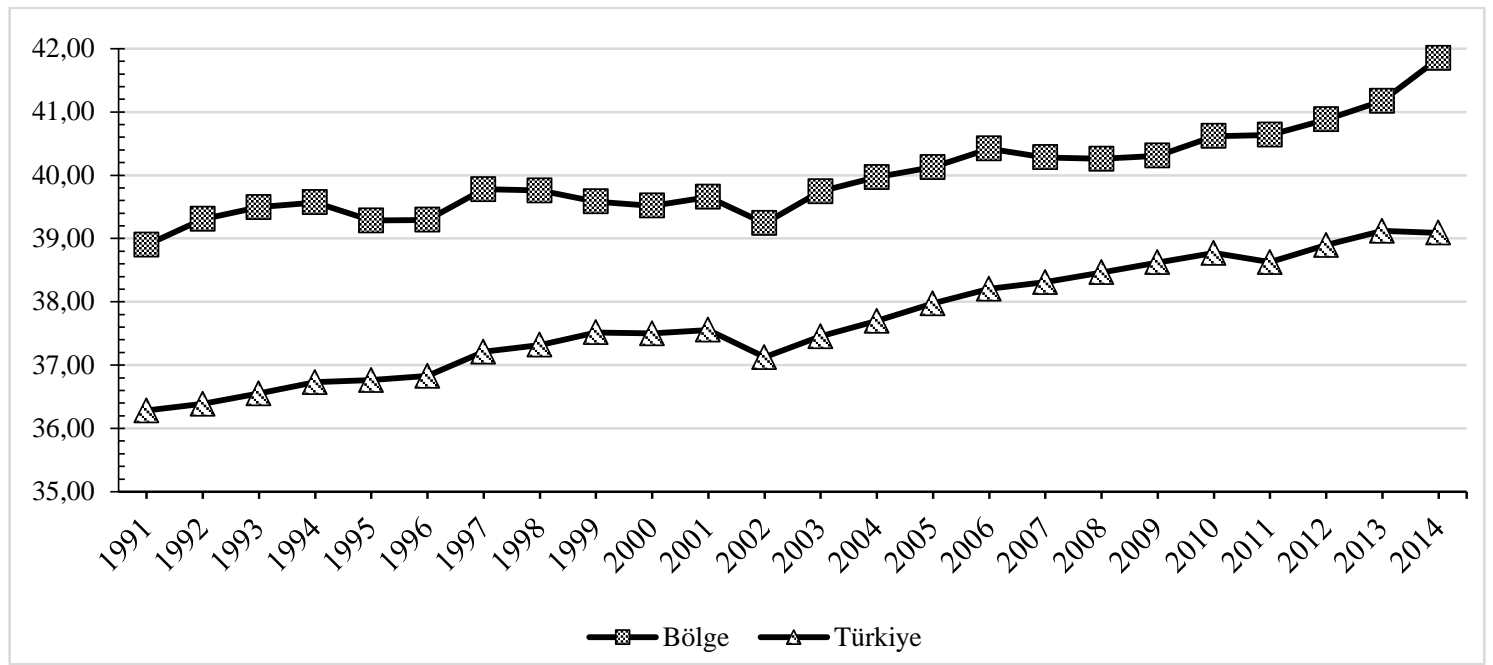

Şekil 5. Orta Anadolu Bölgesi ve Türkiye’nin 1991-2014 yılları arasındaki ortalama traktör gücü değişimi [15]

Orta Anadolu Bölgesi illeri, Bölge ortalaması ve Türkiye geneli için 2015-2023 yıllarına yönelik traktör parkı projeksiyonu Tablo 3'te verilmiştir. Elde edilen sonuçlara göre, önümüzdeki dokuz yıllık dönem içerisinde, Niğde ili hariç Orta Anadolu Bölgesi illeri, Bölge ortalaması ve Türkiye’nin traktör parkındaki artışın son yirmi dört yılda olduğu gibi artmaya devam edeceği öngörülmektedir. 2013 yılından itibaren azalmaya başlayan Niğde ilinin traktör sayısı öngörülen tahminde de \% 18,93 oranında azalarak 16757 'den 14090'a gerileyeceği beklenmektedir.

Bölge illeri içerisinde Aksaray’ın \% 50,96’lık artışla traktör sayısında en fazla artışın olduğu il olacağı tahmin edilmektedir. Bu ilde traktör sayısının 16353'ten 24686’ya yükselmesi beklenmektedir.

Orta Anadolu Bölgesi'nde Aksaray ilinden sonra traktör sayısının en çok artacağı illerin Kayseri ve Sivas olması beklenmektedir. Kayseri ilinin traktör sayısı \% 31,06 artışla 19644'ten 25746'ya çıkacağı 
öngörülmektedir. Sivas ili ise \% 21,74'lük artışla Kayseri'yi izlemekte ve ilde traktör sayısının 20029'dan 24383'e yükselmesi beklenmektedir. Yapılan projeksiyonda bölge illeri içerisinde traktör sayısında en az artışın beklendiği il Yozgat olmuştur. Buna göre ilde \% 3,13'lük bir artış beklenmekte ve traktör sayısının 24738'den 25512'ye çıkacağ1 öngörülmektedir. Traktör sayısında en az artı̧ıın olacağ1 Yozgat ilini sırasıyla Nevşehir, Kırıkkale ve Kırşehir illeri izlemektedir. Bu illerdeki artışın ise sırasıyla \% 4,86, \% 9,54 ve $\% 10,02$ şeklinde olması beklenmektedir.

Ayrıca son yirmi dört yılda olduğu gibi 2023 yılı tahminlerinde de bölge illeri içerisinde traktör sayısının en az olduğu iller 8957 adet ile Kırıkkale ve 8288 adet ile Kırşehir olması beklenmektedir. 2023 y1lı projeksiyonunda bölge illeri içerisinde en çok traktöre sahip ilin 25746 adet ile Kayseri olacağı öngörülmektedir.

Traktör parkı için yapılan 2015-2023 yılları projeksiyonunda Orta Anadolu Bölge ortalamasının bölge illerinde olduğu gibi \% 12,93'lük artışla 130664 'ten 147556 'ya çıkacağı tahmin edilmektedir. Türkiye genelinin traktör parkında ise \% 21'80'lik bir artış beklenmekte, bu artışla birlikte Türkiye'nin traktör parkının 277617 adetlik artışla 1273181'den 1550798'e yükseleceği öngörülmektedir.

Tablo 3. Orta Anadolu Bölgesi illeri, Bölge ortalaması ve Türkiye geneli için 2015-2023 yılları traktör parkı tahmini (adet)

\begin{tabular}{ccccccccccc}
\hline Yıllar & Aksaray & Kayseri & Kırıkkale & Kırşehir & Nevşehir & Niğde & Sivas & Yozgat & Bölge & Türkiye \\
\hline $\mathbf{2 0 1 5}$ & 16353 & 19644 & 8177 & 7533 & 16864 & 16757 & 20029 & 24738 & 130664 & 1273181 \\
$\mathbf{2 0 1 6}$ & 16950 & 20338 & 8268 & 7627 & 16977 & 16594 & 20400 & 24846 & 132775 & 1303408 \\
$\mathbf{2 0 1 7}$ & 17655 & 21051 & 8362 & 7722 & 17087 & 16383 & 20811 & 24950 & 134887 & 1334489 \\
$\mathbf{2 0 1 8}$ & 18478 & 21785 & 8457 & 7816 & 17194 & 16123 & 21268 & 25051 & 136999 & 1366669 \\
$\mathbf{2 0 1 9}$ & 19427 & 22537 & 8554 & 7910 & 17297 & 15814 & 21774 & 25149 & 139110 & 1400165 \\
$\mathbf{2 0 2 0}$ & 20512 & 23310 & 8652 & 8005 & 17398 & 15456 & 22335 & 25244 & 141222 & 1435166 \\
$\mathbf{2 0 2 1}$ & 21744 & 24102 & 8752 & 8099 & 17496 & 15050 & 22953 & 25336 & 143333 & 1471839 \\
$\mathbf{2 0 2 2}$ & 23132 & 24914 & 8854 & 8193 & 17591 & 14594 & 23635 & 25425 & 145445 & 1510336 \\
$\mathbf{2 0 2 3}$ & 24686 & 25746 & 8957 & 8288 & 17684 & 14090 & 24383 & 25512 & 147556 & 1550798 \\
\hline
\end{tabular}

Orta Anadolu Bölgesi illeri, Bölge ortalaması ve Türkiye geneli için 2015-2023 yıllarına yönelik ortalama traktör gücü tahminleri Tablo 4'te verilmiş̧ir. Elde edilen sonuçlara göre, yapılan projeksiyonda, Niğde ili hariç Orta Anadolu Bölgesi illeri genelinde ortalama traktör gücünde artış olacağı beklenmektedir. Bölge illeri içerisinde sadece Niğde ilinde traktör parkında olduğu gibi azalmanın devam edeceği tahmin edilmektedir. Ayrıca bölge ortalaması ve Türkiye'nin ortalama traktör gücündeki artışın son yirmi dört yılda olduğu gibi artmaya devam edeceği öngörülmektedir. 1991-2014 yılları arasında da dalgalı bir seyir izleyen Niğde ilinin ortalama traktör gücü önümüzdeki dokuz yıllık dönemde de \% 2,58 azalarak 36,92 kW’tan 35,99 kW’a gerileyeceği beklenmektedir.

Orta Anadolu Bölgesi içerisindeki iller arasında belirlenen projeksiyonda, ortalama traktör gücünde en az artışın \% 0,63'lük artış ile Yozgat ilinde olması beklenmektedir. Bu ilde ortalama traktör gücü 42,99 kW’tan 43,26 kW'a çıkması beklenmektedir. Yozgat ilini sırasıyla \% 2,66 artış ile Kırşehir ve \% 4,43 artışla Kırıkkale illeri izlemektedir. Kırşehir ilindeki artışın her ne kadar az olsa bile 2023 yılı tahmininde Sivas'ın ardından 46,72 kW ile bölge illeri arasında ikinci sırada yer alması öngörülmektedir.

Ortalama traktör gücünde en fazla artışın tahmin edildiği il Nevşehir olmuştur. Bu ilde \% $12,03^{\prime}$ lük bir artış beklenmekte ve ortalama traktör gücünün 41,16 kW'tan 46,11 kW'a çıkacağı tahmin 
edilmektedir. Ortalama traktör gücünde artışın en fazla olduğu Nevşehir ilini Aksaray, Sivas ve Kayseri takip etmekte olup bu illerde sırasıyla \% 9,89, \% 8,93 ve \% 8,63'lük bir artı̧̧ beklenmektedir. Ayrıca bu illerin 2023 yllı tahmininde ortalama traktör güçleri Aksaray için 43,89 kW, Sivas için 47,21 kW ve Kayseri için 46,22 kW şeklinde olacağı öngörülmektedir.

Orta Anadolu Bölgesi’nin 2015-2023 yıları için öngörülen ortalama traktör gücü tahmininde \% 1,96'lık bir artış beklenmekte, bu artışın 41,91 kW olan gücü 42,73 kW'a taşıması beklenmektedir. Bu sonuç bölge ortalamasının Niğde ve Kırıkkale illeri hariç diğer illerin ortalamasının altında kaldığını göstermektedir. Türkiye’nin ortalama traktör gücü tahmininde ise \% 2,75'lik artışla birlikte 39,66 kW olan ortalama gücün 40,75 kW'a çıkması öngörülmektedir. Türkiye'nin ortalamasının, bu artışa rağmen Orta Anadolu Bölgesi ve bölgedeki illerden Kırıkkale ve Niğde hariç tamamının altında kalacağı tahmin edilmektedir.

Tablo 4. Orta Anadolu Bölgesi İlleri, Bölge ortalaması ve Türkiye geneli için 2015-2023 yılları ortalama traktör gücü tahmini (kW)

\begin{tabular}{ccccccccccc}
\hline Yıllar & Aksaray & Kayseri & Kırıkkale & Kırșehir & Nevşehir & Niğde & Sivas & Yozgat & Bölge & Türkiye \\
\hline $\mathbf{2 0 1 5}$ & 39,94 & 42,55 & 38,37 & 45,51 & 41,16 & 36,92 & 43,34 & 42,99 & 41,91 & 39,66 \\
$\mathbf{2 0 1 6}$ & 40,29 & 43,00 & 38,19 & 45,66 & 41,70 & 36,80 & 43,81 & 43,03 & 42,01 & 39,80 \\
$\mathbf{2 0 1 7}$ & 40,68 & 43,45 & 38,11 & 45,81 & 42,26 & 36,68 & 44,28 & 43,06 & 42,11 & 39,93 \\
$\mathbf{2 0 1 8}$ & 41,12 & 43,91 & 38,12 & 45,96 & 42,85 & 36,56 & 44,75 & 43,10 & 42,21 & 40,06 \\
$\mathbf{2 0 1 9}$ & 41,59 & 44,36 & 38,24 & 46,11 & 43,45 & 36,44 & 45,23 & 43,13 & 42,31 & 40,20 \\
$\mathbf{2 0 2 0}$ & 42,11 & 44,83 & 38,48 & 46,26 & 44,08 & 36,33 & 45,72 & 43,16 & 42,42 & 40,34 \\
$\mathbf{2 0 2 1}$ & 42,66 & 45,29 & 38,86 & 46,41 & 44,73 & 36,21 & 46,21 & 43,20 & 42,52 & 40,47 \\
$\mathbf{2 0 2 2}$ & 43,25 & 45,75 & 39,39 & 46,57 & 45,41 & 36,10 & 46,71 & 43,23 & 42,62 & 40,61 \\
$\mathbf{2 0 2 3}$ & 43,89 & 46,22 & 40,07 & 46,72 & 46,11 & 35,99 & 47,21 & 43,26 & 42,73 & 40,75 \\
\hline
\end{tabular}

\section{Tartışma ve Sonuç}

Orta Anadolu Bölgesi illeri, Bölge ortalaması ve Türkiye için yapılan 2015-2023 yılı traktör parkı ve ortalama traktör gücü projeksiyonuna göre, sadece Niğde ilinin ortalama traktör gücü ve traktör parkındaki \% değişim azalma şeklinde olmuştur. Ortalama traktör gücündeki en fazla artışın Nevşehir ve Aksaray illerinde olacağı öngörülmektedir. Traktör parkında en fazla artışın ise Aksaray ve Kayseri illerinde olacağı öngörülmüştür. Ortalama traktör gücünde pozitif yönde en az artış Yozgat ili ve Orta Anadolu Bölge ortalamasında gerçekleşmiştir.

Traktör parkında en az artış ise Yozgat ve Nevşehir illerinde meydana gelmiştir. 2023 yılında Orta Anadolu Bölge ortalaması ve Niğde ili hariç Bölgedeki illerin tamamının Türkiye'nin ortalama traktör gücünden daha fazla güce sahip olacağ belirlenmiştir. 2023 yılında, Orta Anadolu Bölgesi ortalama traktör gücünün Kırıkkale ve Niğde illeri hariç, diğer illerin tamamından daha düşük olacağı öngörülmektedir.

Elde edilen sonuçlara göre, 1991-2014 yılları arasında genel olarak ortalama traktör gücü ile traktör parkında artış olduğu görülmüştür. 2023 yılı için yapılan tahmin analizinde de bu artışın devam edeceği belirlenmiştir. Ayrıca, 1991-2014 yılları arasındaki verilerde dikkat çeken önemli bir husus da; özellikle yüksek güç sınıfındaki (38-53 ve 53+ kW) traktör sayısı artışının diğer güç gruplarına göre daha fazla olduğu şeklindedir. Buna bağlı olarak, 2023 yılı projeksiyonunda da artışın bu şekilde devam 
edeceği düşünülmektedir. Traktör parkındaki genel artışa paralel olarak, büyük güç sınıflarının daha fazla artış göstermesi traktör pazarında da bu güç sınıfları payının öne çıkacağını göstermektedir.

Ayrıca, tarım alet ve makinalarının özelliklerindeki değişimin zamanla büyük güç sınıflarındaki traktörlere daha uygun hale dönüşeceği öngörülmektedir. Geleceğe yönelik beklenen bu değişim dikkate alınarak, başta traktör olmak üzere diğer tarım alet-makinaları imalatında da ileriye dönük planlamaların yapılmasının kaçınılmaz olduğunu göstermektedir.

\section{Kaynaklar}

[1] Altıkat S., Çelik A., "Erzurum İlinin Tarımsal Mekanizasyon Özellikleri” Atatürk Üniversitesi Ziraat Fakültesi Dergisi, 40 (2), 57-70, 2009.

[2] Bilim C., Korucu T., Semerci T., "Gaziantep İlinin Tarımsal Mekanizasyon Özellikleri” KahramanmaraşS Sütçü İmam Üniversitesi Doğa Bilimleri Dergisi, 17(2), 14-23, 2014.

[3] Çelik A., Altıkat S., "Türkiye Traktör Parkı ve Yetkili Teknik Servis Ağlarının Markalara Göre Dağılımı” 27. Tarımsal Mekanizasyon Ulusal Kongresi 5-7 Eylül, Bildiri Kitabı, 39-47, Samsun, 2012.

[4] Anonim., "TR7 Orta Anadolu Bölgesi Tarım Master Planı” T.C. Tarım ve Köyişleri Bakanlığı, Strateji Geliştirme Başkanlığı s.18, Ankara, 2007.

[5] Tozan M., Değirmencioğlu A., Güler H., "Hava Akımlı Bir Pülverizatörden Farklı Meme Delik Çapı ve Basınçta Elde Edilen Damla Çaplarını Tahminleme Modelleri” Anadolu Ege Tarımsal Araştırma Enstitüsü Dergisi, 15 (2), 68-86, 2005.

[6] Cankurt M., Miran B., “Aydın Yöresinde Çiftçilerin Traktör Satın Alma Eğilimleri Üzerine Bir Araştırma” Ege Üniversitesi Ziraat Fakültesi Dergisi, 47 (1), 43-51, 2010.

[7] Bek M. İ., "Zaman Serisi Analizi ve Tarımsal Uygulaması" Kahramanmaraş Sütçü İmam Üniversitesi, Fen Bilimleri Enstitüsü, Yüksek Lisans Tezi, Kahramanmaraş, 2008.

[8] Orhunbilge N., "Uygulamalı Regresyon ve Korelasyon Analizi” İ. Ü. İşletme Fakültesi Yayın No: 267, İstanbul, 261s, 1996.

[9] Kadılar C., "SPSS Uygulamalı Zaman Serileri Analizi” Bizim Büro Basımevi, Ankara. 2009.

[10] Ryan B. F., Cryer J., “Minitab Handbook” California, 505s, 2005.

[11] Öztürkcan M., “Regresyon Analizi” Maltepe Üniversitesi Yayınları, No:40, 119s, 2009.

[12] Ünver Ö., Gamgam H., Altunkaynak B., "SPSS Uygulamalı Temel İstatistik Yöntemler” Seçkin Yayıncilık, 488s, Ankara, 2013.

[13] Gujarati D. N., “Temel Ekonometri” Çeviren: Ümit Şenesen ve Gülay Günlük Şenesen, Literatür Yayınları, 972s, İstanbul, 2012.

[14] Özarıcı Ö., "Farklı Not Sistemlerinde Öğrencinin Başarılı Olma Olasılı̆̆ının Probit Regresyon Analiziyle Değerlendirilmesi” Osmangazi Üniversitesi, Fen Bilimleri Enstitüsü, Yüksek Lisans Tezi, 1996.

[15] Anonim., “Tarım Alet ve Makine Sayıları” Türkiye İstatistik Kurumu (TÜIK), http://tuikapp.tuik.gov.tr/bitkiselapp/tarimalet.zul. Erişim: Ocak 2015. 